\title{
Eptonyms in German: An Attempt of Typological Distinction (on the Example of Maxims and Aphorisms)
}

\author{
Nataliia Onishchenko \\ Vasyl Karazin National University Kharkiv, Ukraine \\ Tetiana Smoliana \\ Vasyl Karazin National University Kharkiv, Ukraine \\ Maryna Miroshnychenko \\ Vasyl Karazin National University Kharkiv, Ukraine
}

\begin{abstract}
The present paper provides an outline of the German eptonym, as a quotation-like utterance that can be traced back to the name of its real or alleged author, a precedential text / a part of a precedential text connected with the concept AUTHOR. The eptonyms are examined from the point of view of the specifics of the AUTHOR's position regarding the topic of the utterance determining the type of eptonym. The four-step algorithm shown in the paper involves modelling the degree of the author's personality prominence in the eptonym. Two polar points - maximal social experience and maximal individualised author-based approach are represented in the eptonymicon by maxims and aphorisms respectively. It is stated that the maxim objectifies the moral norms of a certain national language collective. It is rational, contains an immanent moral component, has a directive character, explicates the rules of behaviour, ethical principles, objective laws, norms. The aphorism is paradoxical, reflecting the depth and originality of individual author's multi-vector thought, formal symmetric, dialogic, breaking the rules of formal logic. The provided method can be used with the purpose of distinguishing and defining other types of German eptonyms.
\end{abstract}

Index Terms - aphorism, concept, author, citation, eptonym, maxim

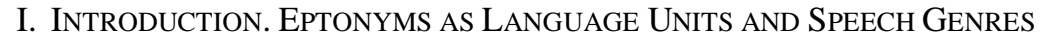

The cognitive-discursive paradigm that now prevails in modern linguistics rejects the idea of mechanical objectification of knowledge available to humans through their language. Instead it dwells on "communicative interaction of the subjects, the purpose of which is to elaborate a common system of orientations in the living space based on the formation of language signs" (Martyniuk, 2012, p. 79). This approach shifts the focus of the linguistic research of language units as carriers of meaning to the construction of meaning by the speaker, based on his communicative competence and goals, strategies and experience, the unique configurations of which form a conceptosphere of various dimensions (from individual to supranational).

The organization of the verbalized human knowledge is partially optimized by "templates", block units prepared to usage in speaking praxis, e.g. proverbs, idioms, etc. A part of this group is so called eptonyms. These are defined by Diadechko (2002) as recurrent quotation-like utterances, which can be traced back to the name of their real or alleged author (p. 144). They are viewed ambivalently by traditional linguistics: on the one hand, they are language units of the phraseological type (they are peripheral in the phraseological system); on the other hand, they are defined as precedent texts (Karasik, 2002). The latter accents on the Author as an integral part of the eptonymic meaning structure. Aphorisms, sentences etc are tightly associated with a precedent person (their real or fictional author). There is a number of eptonyms with an author whose identity cannot be proved; on the other hand, the most eptonyms origin from fiction, speeches or interviews etc of precedent people. One of the most quoted German authors Johann Wolfgang Goethe is the proved author of the well-known quotation wie ein roter Faden durchziehn (literally 'red thread runs through smth') as a notion of something important, cross-cutting, covering an action (*all the translations of German eptonyms are done by the authors except of extra specified):

(1) Wir hören von einer besondern Einrichtung bei der englischen Marine. Sämtliche Tauwerke der königlichen Flotte, vom stärksten bis zum schwächsten, sind dergestalt gesponnen, dass ein roter Faden durch das Ganze durchgeht, den man nicht herauswinden kann, ohne alles aufzulösen, und woran auch die kleinsten Stücke kenntlich sind, dass sie der Krone gehören. /“Wahlverwandtschaften", Teil 2, Kapitel 2/

'There is, we are told, a curious contrivance in the service of the English marine. The ropes in use in the royal navy, from the largest to the smallest, are so twisted that a red thread runs through them from end to end, 
which cannot be extracted without undoing the whole; and by which the smallest pieces may be recognized as belonging to the crown.' "Elective Affinities", Part 2, Chapter 2/

*translated by R. J. Hollingdale

(2) Ebenso zieht sich durch Ottiliens Tagebuch ein Faden der Neigung und Anhänglichkeit, der alles verbindet und das Ganze bezeichnet. /"Wahl-verwandtschaften", Teil 2, Kapitel 4/

'Just so is there drawn through Ottilie's diary, a thread of attachment and affection which connects it all together, and characterizes the whole.' /"Elective Affinities", Part 2, Chapter 4/

*translated by R. J. Hollingdale

The most phraseological dictionaries of German define this quotation as an idiom (which can be the next stage of the eptonymical development - after their loss of affiliation with the author's image).

\section{EPTONYMS AS Author-BASEd Units: Hypothesis, Methods AND Materials}

\section{A. The Role of Author in Eptonyms}

The eptonyms are a result of interaction of their authors and speakers - both language personalities, producing and reproducing the utterances.

Both author and speaker are "[...], a person who exists in the language space - in communication, in behavioral stereotypes fixed in speech, in the meanings of language units and the contents of texts" (Karasik, 2002, p. 11). Speech consciousness of a person is, according to Krasnykh, the most important component of the speech organization of a person and consists of various types of mental formations (Krasnykh, 1998). Language personality is characterized by units of thinking and their language objectification, but only if they find their manifestation in speech genres (Karasik, 2002, p. 19).

By quoting an elite speech personality, the speaker increases his communicative status in all types of competence, so he achieves communicative leadership. The desire for dominance in communication and increasing the communicative status encourages quoting informative and formal non-trivial statements while simultaneously appealing to the concept of their author as an elite speech personality. The authors of numerous eptonyms that acquire cultural significance can be called precedential personalities.

Most German eptonyms are associated with the precedent-setting personality of Johann Wolfgang Goethe, whose creative heritage covers almost all spheres of human spiritual activity. Svasyan (1989) says about Goethe:

Goethe was a poet, naturalist, novelist, philosopher, scientist, critic, esthetician, politician, teacher, administrator, translator, traveler, ironist, erotomaniac, occultist, sage, seer, physiognomist, minister, painter, polymath, charmer. Goethe's natural interests included biology, botany, zoology, anatomy, osteology, optics, physics, physiology, chemistry, meteorology, and geology. He was the creator of comparative anatomy, modern plant morphology, physiological optics, the concept of homology, morphological type, metamorphosis, and the idea of the ice age. (p. 5-6)

To a certain extent, Goethe was not only "the creator of the German language as a significant one in the market of European peoples" (Svasyan, 1989, p. 8), but also a harbinger of Postmodern aesthetics with its emphasis on anthropocosmism, which covers man, nature, the cosmos, and the universe. Goethe's aphorisms demonstrate decentralization, fragmentation, paradoxicity, eclecticism, self-reflection, and play. This is also evidenced by the fact that Goethe is not characterized by the classical absolutization of authorship, he criticized the German meticulousness in determining authorship, which still exists today (for example, Goethe did not clearly distinguish between the authorship of his poems and Friedrich Schiller). He considered the main existence of the poem, and not its authorship, and he often borrowed plots and techniques from other poets. The paradoxical and oxymoronal Postmodernism sprouts into the numerous contradictions of Goethe's personality: "a thinker, but not a speculator, an open- minded mystic and a sober magician - a spirit that combines passion with discretion, extravagance with moderation" (Baumann, 1997, p. 171).

Another possible explanation for Goethe's citation is the positivity of his creative thinking and attitude to the man and the world. There is no distrust in Goethe's skepticism, no bitterness in his refusal, and cynicism and sharpness are alien to him. The dictionary of "evil quotes" (Tange, 1997) contains only 9 aphorisms of Goethe. In total, the main quote portals contain more than 3,000 Goethe quotes (for example, a popular website Aphorismen.de contains 3,525 quotes from the author).

\section{B. Research Hypothesis}

The assignment of quotations of precedential personalities to the category of eptonims, proverbs, idioms depends, on the one hand, on the approach of the compilers of lexicographic sources. Often it consists in systematizing eptonims according to the principle of frequency of use in modern texts. Conducted by Minayeva and Pogrebenko (Minayeva and Pogrebenko, 2001, p. 105) analysis of sources of quotations recorded by the Cambridge International Dictionary of English and Oxford Dictionary of Quotations showed that the expressions of famous people in both dictionaries have the third rank of frequency (the first is the quotes from fiction, which also does not exclude an appeal to the author's concept). The precedent of German-speaking personalities (Goethe, Schiller, Hegel and others) is also proved by the criterion of "textual violence", identified by Slyshkin (Slyshkin, 2000, p. 72), which is understood as acquaintance with the text/author despite the intention of the recipient, under the influence of another person, institution, etc. The most 
common form of textual violence is the inclusion of text in the compulsory school curriculum - this explains why the largest number of quotes used in German comes from Goethe's "Faust". Thus, under the influence of the authority of the speech personality, the apt expression becomes a quote, the quote becomes an eptonym, and after the weakening or loss of connection with the concept, THE AUTHOR, as a result of frequent use and conventionalization, becomes an idiom or phraseological unit of another type, see Figure 1:

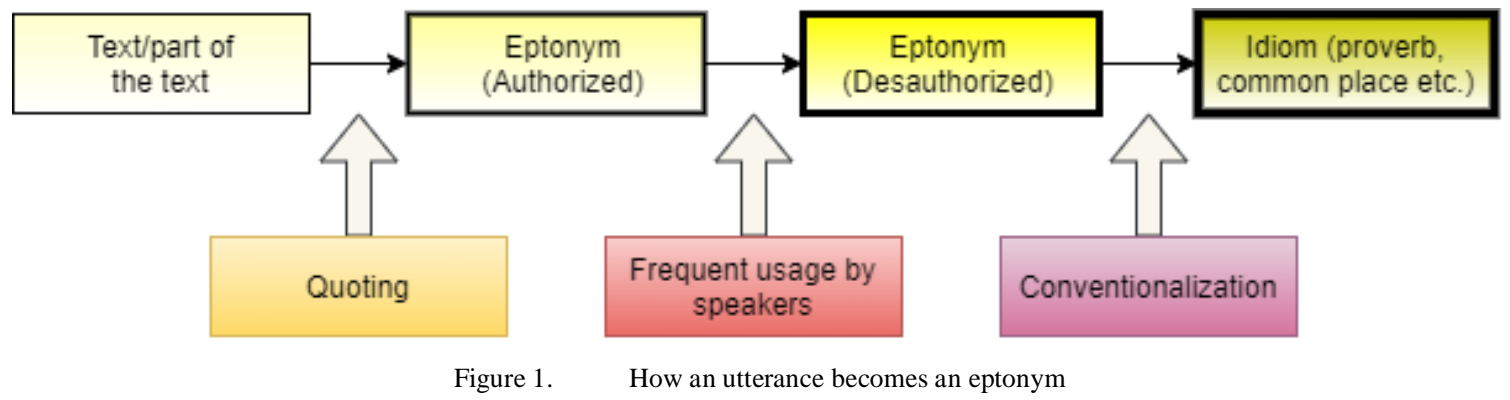

The hypothesis of our research is a statement about the importance of the role of the author and his position regarding the topic/content of the utterance in determining the type of eptonym and distinguishing closely related eptonymic genres. It is based on the typology of Berkov and Berkova (2000), who distinguish "gnomic" quotes (by types of information), which are some generalization of human experience and life wisdom, "characterizing" quotes with a figurative form, and "aesthetic" quotes with an ornamental function (p. 11), as well as a pragmatic function. It forms the basis for the speaker's "connection" of the author's concept to the informative content of the eponym in its functioning in person-oriented and status-oriented communication. Karasik (2002) says that "these units ensure clichéd discourse, compliance with certain genre canons [...]. When the speaker makes cliché, it is as if he puts on the mask of a representative of an institutional group" (p. 23).

The author of the eptonym is traditionally seen as an elite language personality, as Sirotinina (1998) believes: a person who has an advantage over other native speakers from the point of view of encyclopedic, linguistic and interactive competence.

\section{Method and Algorithm}

The study uses the method developed by us to determine the influence of "individuality and unconventionality" on the content of the eptonym - that is, the influence of the author's elite personality. This method was implemented using the following algorithm:

1. the first step is to identify citations of prominent personalities in modern discourses (for example, journalistic, bibliographic, social media discourse, etc.).

2. the second step is to find the original author's work from which the quote is derived. This can be either a largescale work (novel, short story), or an intentional aphorism, which was conceived by the author as a potential quote.

3. at the third stage, contextual and comparative analysis takes place, which is aimed at identifying the degree of preservation of the author's original intention. That is, to what extent the quoting language personality conveys by quoting what the author of the source text wanted to convey to the reader. As a rule, it turns out that the distortion of the author's intention by the quoted language personality can be conscious (then we can talk about parody or stylization) and unconscious. For example, Napoleon's phrase Hier ist die Sonne von Austerlitz (Here comes the sun of Austerlitz), which metaphthonymically conveys the mood of victory, is now mostly used by native German speakers simply to refer to sunrise.

4. the fourth step involves modelling the degree of prominency (highlighting) of the author's personality when quoted in modern discourses.

Although the development of an accurate scale of correspondence of the cited speech genres to the level of transmission of "author's identity" is still one of the prospects for future research, the above algorithm made it possible to rather roughly divide the maximum and minimum author's identity into poles. At one of the poles there is a minimum individuality and maximum presentation of the laws and norms of society (maxim), at the other pole the author's individual view of the world is presented as much as possible, often contrary to utilitarian norms, reflected in language practice in paremic genres like proverbs, sayings, common places. This maximally "individualized" genre is an aphorism. The influence of individual and social factors on the formation of these genres is shown in Figure 2: 


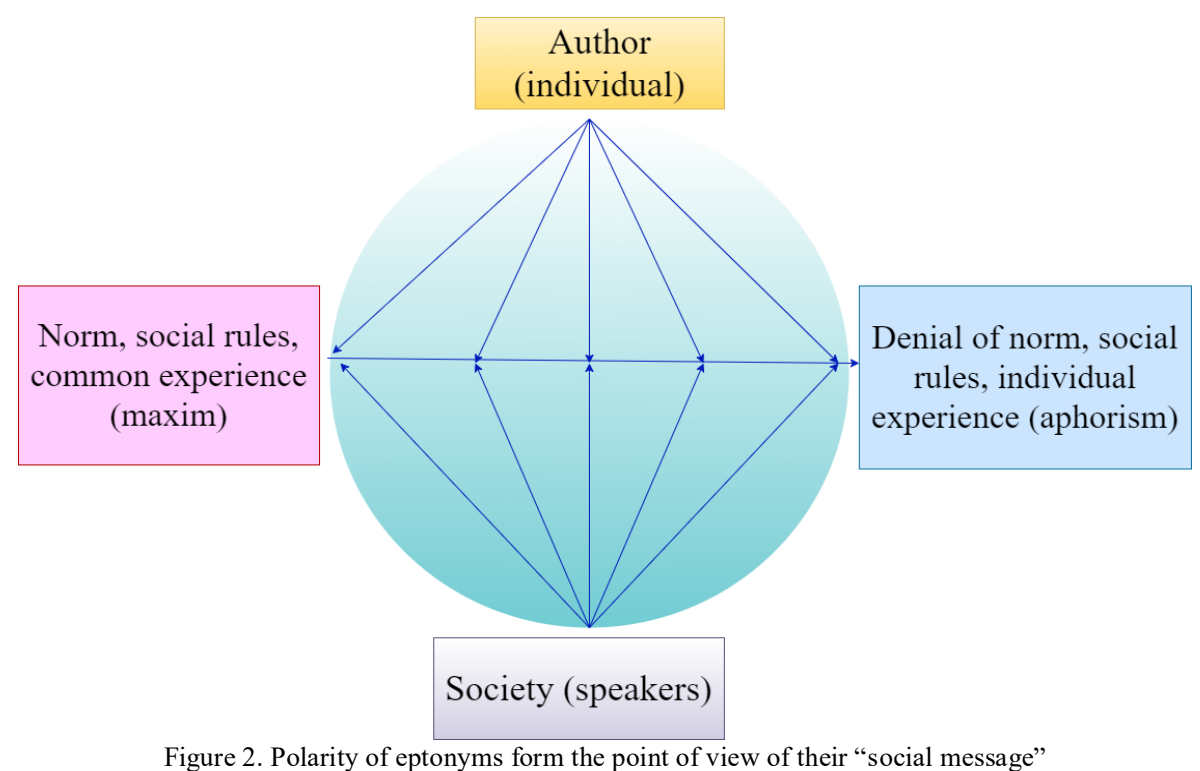

Such separation of aphorisms and maxims will allow us to clarify their basic definitions later, because, according to popular opinion, maxim is understood as a kind of aphorism (Modern explanatory dictionary, 2003), and this comes into conflict with the thesis about the difference in their "social messages".

\section{Material}

The sources of the primary material of maxims and aphorisms in the context of modern discourses (primarily publicistic) were primarily online versions of the leading periodicals in German-speaking countries (for example, Frankfurter Allgemeine, Süddeutsche Zeitung, Der Spiegel, Focus, etc.). The markers of the needed quotes were language clichés ("As N said...", "As someone from the great ones said...", "as they say...") or graphic signs (quotation marks). The authorship of quotations and the source of their origin were found due to printed and online German dictionaries of quotations and aphorisms ("Datenbank der 75.000 Aphorismen", "Das große Z", "Die ZitateWelt", "Lexikon der boshaften Zitate", "Zitate online", "Zitate und Sprüche", etc.). In addition, original works of German authors (novels, poems, short stories, etc.) were involved in the citation material.

\section{RESULTS AND DisCUSSION}

\section{A. Maxim as an Eptonym}

The German maxim is a type of aphorism, which, along with aphorisms, maxims, chreiai, apothegms, velirisms and other microtexts, is poorly studied and has its functional significance as a separate type of eptonym.

Maxim is a stable in form and content expression of moralistic-instructive nature and incentive character. Maxim is distinguished from the related microtexts by a number of features. Microtexts related to maxim and aphorism also include a sententia, since the boundaries of aphorism as a genre are blurred, - an expression of moral and instructive content, a certain philosophical observation, a short instruction that demonstrates life as it is or should be in a direct or allegorical, encouraging or discouraging form (Koloiz, 2014, p. 341). The definition of maxims includes literary statements of a particular author, it is considered not only as a cultural model, but also as a part of the linguistic picture of the world, explicates significant and typical components of the national picture of the world, appeals to the highest norms of society, reflects the cognitive experience of a certain society.

Researchers are also of the opinion that maxim is a moralistic kind of sententia / apothegm. If the sententia is used quite often, and its content is generalized, then it can pass into the category of proverbs. In this case, the origin of such a saying will be known, which is not typical of most proverbs (Ivanov, 2001, p. 278). But this, in our opinion, cannot be a starting and good criterion for determining, since the author of maxim and aphorism is almost always known, or we feel the seal of authorship (according to Dyadechko, 2002).

Morality as an optional feature of a maxim is the main difference between these related microtexts; this feature is mandatory for a maxim.

(3) Alles verstehen heißt alles verzeihen.

'To understand everything means to forgive everything'

(4) Der Starke ist am mächtigsten allein. /Friedrich Schiller/

'The strong man is strongest when alone' /Friedrich Schiller/

Related to maxim and aphorism there are such archaic microtexts as chreia, apophegm and gnome. The most common classification is based on genological and semantic differences. 
Gnome (Latin gnome) is a generalization of reality in the form of instructive statements, usually poetic and anonymous, or spoken on behalf of its author, according to Ivanov (Ivanov, 2001, p. 217). Between the maxim and the gnome, either an identity sign is placed, or it is called an "impersonal sentential", which takes an intermediate position between an anonymous proverb and individualized author's aphorism (Gasparov, 2001; Ivanov, 2001), an expression of instructive and philosophical content (Gasparov, 2001, p. 165).

The gnome did not become a genre definition, although similar forms of didactic poetry are known in European literature (for example, Goethe) (Gasparov, 2001). It should be noted that in case of versification, which is observed in the definition, it is impossible to identify a gnome with either a sententia or a maxim, since the author of the latter is almost always known, and there is no rhyme in it at all.

(5) $O$ weh der großen Babylon!

Herr, tilge sie von deiner Erden,

Laß sie im Pfuhl gebraten werden,

Und, Herr, dann gib uns ihren Thron. /Johann Wolfdang Goethe/

'O woe to the great Babylon!

O Lord, wipe her from your Earth,

Let her be roasted in the lake,

And, Lord, then give us her throne' /Johann Wolfgang Goethe/

So, the differential features of the maxim that distinguish it from the gnome are its non - validity and mandatory authorship, but the composition of the gnome may contain a moralistic instructive directive expression - maxim. Gnomes are not characterized by brevity; signs of rationality and morality, unlike maxima, are optional.

Chreia (Latin hria) - a statement in which the generalization of reality cannot be separated from the life situation that "provoked" its appearance; this is a short, concise transmission of a thought according to Gasparov (2001, p. 165). Chreia is considered as a short anecdote created around an instructive aphorism or action of a great man (Gasparov 2001, p. 165; Ivanov, p. 2001, 218). For chreia, it is typical to convey someone's direct or indirect speech.

From the example, we can see that chreia is an aphorism combined in a situation:

(6) Mose aber erzitterte und wagte nicht, es zu betrachten. Der Herr aber sprach zu ihm: „Löse die Sandale von deinen Füßen, denn der Ort, auf dem du stehst, ist heiliges Land“/Das Neue Testament, Apostelgeschichte 7:32-33, p. $282 /$

'Then Moses trembled, and durst not behold. Then said the Lord to him, Put off thy shoes from thy feet: for the place where thou standest is holy ground' /New Testament, Acts, 7:32-33/

* King James Bible

In the example, direct speech is a maxim. Therefore, we can conclude that the difference between maxim and chreia is not only the presence of direct/indirect speech in the latter, but also a specific situation.

For chreia, the optional feature is didacticism, rationality, and morality, which makes it related to the maxim in which these are mandatory.

Apothegm (Latin apothegm) is an aphoristic expression that is explicitly attributed to a certain author ("placed in the mouth of a particular person"), usually a well-known historical figure, based on the presence of textual sources, or on gossips according to Ivanov (Ivanov, 2001, p. 218). The apothegm contains a moral and other advice expressed in the form of an appeal to the interlocutor (Ivanov, 2001, p. 215).

It is quite difficult to distinguish apothegm from chreia, since the definition of both statements emphasizes the presence of direct speech.

It is noted that "too often we meet such typical for apothegm single statements and anecdotes that refer to a certain experience" (Dodel, 1997, p. 24). Dodel (1997) writes: "If we look closely at the literary form that we encounter in the apothegm, the external form corresponds to the internal one" (p. 24-25). It should be emphasized that experience is directly explicated in the text.

An apothegm is an aphoristic expression that contains instructive/declarative content. The starting criterion for distinguishing apothegm from chreia is situationality, which is typical for chreia and not typical for apothegm.

It should be noted they have the common features with maxim. Direct speech as a part of apothegm, if it is considered as a separate expression and contains moralistic / instructive signs, is a maxim:

(7) Einen Propheten wie mich wird euch Gott aus den Brüdern erwecken, gleich mir. Auf ihn sollt ihr hören in allem, was er zu euch reden wird. /Das Neue Testament, Apostelgeschichte 3:22. p. 272/

'For Moses truly said unto the fathers, A prophet shall the Lord your God raise up unto you of your brethren, like unto me; him shall ye hear in all things whatsoever he shall say unto you' /New Testament, Acts, 3:22/

* King James Bible

The difference between the maxim and the above-mentioned related microtexts is in its formal features, not its content. Maxim is not characterized by the versification of gnomes, the introduction of direct speech typical of chreia, and the description of the corresponding situation containing apothegm.

Maxim also has similar features with noneptonic microtexts like proverbs. A proverb is a stable expression of folklore origin, often rhythmic in structure, involving the generalized experience of the people and their assessment of various events and phenomena; for the most part, it does not have a generally accepted definition, contains a different 
set of differential features; it is an independent judgment, formed as a simple or complex sentence having its own intonation and grammar; it has a generally metaphorical instructive content, pragmatic meaning, etc (Koloiz, 2014, p. 341).

Maxim does not have such a fairly common thematic classification as proverbs (a person and the environment, attitude to food and leisure or everyday life, understanding of life values, attitude to the surrounding animal world and climatic conditions a person lives in, attitude to money and material values, a person in the context of his history).

Maxim can also be of folklore origin, accumulate people's experience, appeal with its content to a person, his character, actions and relationships in the family or society. The following signs can be called differential for maxims and proverbs: paradoxicality will always be optional for maxims, the maxim being categorical. A proverb, as a rule, contains irony, its relevant rhyme and rhythm, it seeks aesthetic influence and is a metaphorical expression.

Therefore, the German maxim can be interpreted as a unit of not only the phraseological, but also the paremiological fund of the language, since paremias also have a kind of an author - represented by the entire national language collective.

The implementation of the maxim depends on the communicative intention of the addressee/addresser in communication, which allows us to talk about such a differential feature of the maxim as intentionality.

The leading intention of the maxim is to encourage a person to comply with certain norms/rules dictated by a society, which are considered to be manifestations of morality in it.

Using maxim in communication, the addresser appeals to common knowledge with the addressee, since he seeks to exert a certain influence on the latter, thereby regulating his behavior. So, this indicates another feature of the maxim its regulatory function. Maxim serves to regulate compliance with the norms of behavior and a certain condition of a person.

In favor of the fact that it is regulatory function that is the main differential feature of the maxim, there are statements proving that language is not an instrument used for regulation, but a tool of regulation that has a semiotic nature (Martyniuk, 2006) (this concerns the maxim as a language entity), that speech is a means of regulation, since it is in no case caused by a regulatory effect (Blakar, 1987, p. 134) (this concerns the maxim as a speech unit).

Being actualized in the discourse, maxim reveals its cognitive and communicative features, and its discursive implementation forms a fragment of discourse, which in its speech characteristics is an intertext, and in its mental and communicative properties is a unity formed by a common meaning aimed at achieving a regulatory effect. Maximum regulatory potential of the maxim is manifested in religious and journalistic discourses.

Moral values and principles, norms and rules of behavior of the individual have appealed to the commandments of Christ and his philosophy since ancient times, so religious discourse is an "ontogenetic" discourse for maxim. Research in the field of modern philological sciences indicate an increased interest in the Bible as the oldest example of a megatext that determines the ideological positions of society, the main aspects of culture, existence and civilization.

Establishing the highest values and rules of behavior of an ethnic group, maxim actualizes (explicitly or implicitly) such concepts as FAITH, KINDNESS, LOVE, DUTY, TOLERANCE, JUSTICE, HONESTY, ORDER, REPENTANCE, MODESTY, the megaconcept for which is THE RULE OF BEHAVIOR. Under megaconcepts we mean those basic concepts that represent universal concepts.

Since the maxim explicates the norm of behavior, regulatory concepts corresponding to the functional characteristics of the maxim will be relevant for studying.

\section{B. Aphorism as an Eptonym}

Aphorism as a separate genre is characterized by the following features:

1. deep and original thought, which reveals the author's personality;

2. general judgment, which contributes to the depth and truth of thought;

3. brevity, which deepens the content of the aphorism, and which is aimed at its better memorizing and increasing the pragmatic effect;

4. clarity, refinement, expressiveness of thought;

5. perfection, semantic completeness;

6. aesthetic completeness, artistry that combines wisdom and beauty of expression.

The aphorism is characterized by paradoxicity, it contradicts the generally accepted opinion and should be unexpected, unusual and affect the consciousness of the reader/addressee with these features. The laws of logics are optional for the aphorism, it is an individualistic expression, it is a personal opinion that strives for a stunning effect. The aphorism often calls into question some experience, while the maxim, on the contrary, states the truthfulness of the judgment, the need to perform or not certain actions. Thereafter, maxim denotes the generalized life law/experience of an individual or society. Maxim does not strive for an extraordinary pragmatic effect, does not question it, and does not contain paradoxes. Aphorism, unlike maxim, is not a synthesis of human wisdom, does not affect consciousness with deep truth, a comprehensive understanding of the phenomenon. The subject of aphorisms is quite broad, but maxim has a moral and ethical orientation. However, the fact that maxim is a moralistic expression, standard behavior, and the aphorism means lack of standards, proves that it was the maxim that the development of aphorism in its current understanding and general definition began with. 
The main features of the aphorism have their own typical linguistic expressions in German: in particular, polemicism and pluralism manifests itself as linguistic dialogism, aesthetic perfection - as a specific phonetic and rhythmic pattern, lexical and syntactic symmetry.

Syntactic parallelism is a separate manifestation of repetition and consists in the complete or partial identity of constructing syntactic constructions, and also implements the principle of symmetry. Since eptonyms are distinguished by "conceptual integrity and semantic completeness", "the ability to express the universal truths" (Korolkova and Tikhonov, 2007, p. 3-4), their symmetrical form corresponds to the symmetry of the function - universalization of contradictions and at the same time balancing the routine experience with non-normative oppositions. This is a manifestation of language iconicity, because "for an adequate reflection of cognitive meanings on the language structure, an individual has a need to algebraize language relations, operating with a "pure" form, the key to clarity and communicative completeness of which will be its aesthetic component" (Koval', 2014, URL). In iconic language phenomena, the language form acquires conceptual properties, and the function changes "from constructive (to expose the principle) to translational-ornamental"' (Koval', 2014, URL).

Traditionally, sound-symbolic phenomena, rhyme and rhythm are studied as iconic language forms, but in the works of Müller, Norrman (Müller, 1999; Müller,2001; Norrman, 1999), based on the material of poetic texts, an increase in the expressiveness of the text is proved, if the meta-sign reference is simultaneously stated in its content structure and transmitted in its material form, namely, if the identity is established in the sequence, the order of events of the surrounding reality and the order of words in the sentence, reflecting these events.

The iconicity of parallel constructions of aphorisms establishes a motivational connection between their form and content, form and function, which also contributes to the processes of conscious imprinting.

On the other hand, repetition is the destruction of syntagmatic system relations, which leads to a violation of the postulate of quantity, to the asymmetry of the sign. The gap between formal symmetry and asymmetry leads to implicitness in the text. If we decompose the text implicate of a parallel construction into the actual text structure and the inference from it, then the latter can be interpreted as a structurally determined semantic increment, redundancy, multiplicity, polyphony.

In aphorisms syntactic parallelism is represented by models with the following inferences:

- simple repetition of the superficial syntactic structure. Against the background of repetition, the focus is on lexical variation, represented by examples (8) antonyms, (9) heteronyms, which emphasizes the pluralism of thought.

(8) Armut ist die größte Plage, Reichtum ist das höchste Gut

/Johann Wolfgang Goethe/

'Poverty is the biggest torment; richness is the highest good'

/Johann Wolfgang Goethe/

(9) Ein Gott ist der Mensch, wenn er träumt, ein Bettler, wenn er nachdenkt /Friedrich Hölderlin/

'Man is a god when he dreams and a beggar when he thinks'

/Friedrich Hölderlin/

- "mirror" repetition. Symmetrical polarity of signs emphasizes the opposition of the concepts verbalized by them, and therefore corresponds to the polemicality of the aphorism:

(10) Die Kunst ist lang, Und kurz ist unser Leben /Johann Wolfgang Goethe/

(nach Hippocrates)

'Art is long, but short are our lives' /Johann Wolfgang Goethe/

(after Hippocrates)

Repetition of the same lexical unit in different syntactic roles (11) or antonymic inversion of both the subject and predicate (12) make it difficult to distinguish between «mirror» repetition and chiasm:

(11) Und doch, welch Glück, geliebt zu werden, Und lieben, Götter, welch ein Glück/Johann Wolfgang Goethe/ 'And well, what kind of a pleasure to be loved, And loving is the greatest pleasure' /Johann Wolfgang Goethe/

(12) Der Einsatz war groß, klein war der Gewinn /Friedrich Schiller/

'Commitments were big, little was the goal' /Friedrich Schiller/

Chiasmus, or reverse parallelism, is a schema that consists of a crosslike change in successive phrases or clauses. Chiasmus itself is the most iconic figure of all parallel language structures (Müller, 2001, p. 308; Norrman, 1999, p. 5982). Its iconicity is intersystemic: chiasmus (from ancient Greek $\chi 1 \alpha \sigma \mu$ ós) as a linguistic phenomenon goes back to counterpost - a technique of depicting a figure in art, in which the position of one part of the body is contrasted with the position of another part. Counterpost dynamizes the rhythm, enables to transmit movement or tension without disturbing the overall balance, enhances the three-dimensionality of the image, the position of balance created from opposite movements. The contrast-symmetric form of chiasmus embodies the paradoxicality of aphoristic meaning (under the paradox, following Karasik, we understand the overlap of two incompatible judgments, the content of which breaks the stereotypical views that exist in society (Karasik, 2002, p. 298).

(13) Am Anfang gehören alle Gedanken der Liebe. Später gehört alle Liebe den Gedanken /Albert Einstein/

'First all the thoughts belong to love. Later all love belongs to thoughts'

/Albert Einstein/ 
Semantic completeness turns chiasmus into a whole text - in particular, an aphorism, a humorous miniature, an epigraph, and so on. In the genre of speech chiasmus has a high rhetorical effectiveness:

(14) Ask not what your country can do for you - ask what you can do for your country /John F. Kennedy's inaugural address/

Chiasmus is characterized by dialogism (according to Bakhtin it is the unity of opposites, the broadest opposition (Bakhtin, 1996), it is constituted by two-voice opposition, horizontal balance, lexical "echo". The dialogism of chiasmus in aphorism is contrasted with the monologue parallelism of proverbs or maxims, for which chiasmus is uncharacteristic.

There are three types of inferences indicated that the chiasmus implicate:

1. Denial of usage, norms. The mutual exclusion of one part of chiasmus by the other one leads to the unambiguity of decoding the implicit meaning and corresponds to the Hegelian antithesis. From a structural-semantic point of view, this type corresponds to syntactic chiasmus, in which the right part is structurally symmetrical to the left, repeating the elements of the left part of the sentence in the reverse order:

(15) Die Ersten werden die Letzten und die Letzten werden die Ersten sein /Matthäus/.

'So the last shall be first, and the first last' /Matthew/.

* King James Version

2. Equilibrium is based on the antonymic inversion of each of the components, which results in synthesis. The semantic complexity of such a chiasmus is achieved by inverting the meanings of its parts and exchanging of syntactic functions:

(16) Heirat heißt seine Rechte halbieren und seine Pflichten verdoppeln /Arthur Schopenhauer/;

'Marrying means to halve one's rights and double one's duties' /Arthur Schopenhauer/

*translated by T. B. Saunders

(17) Es bildet ein Talent sich in der Stille, sich ein Charakter im Strom der Welt /Goethe/

'A talent is formed in silence, a character in the flow of the world' /Goethe/

3. Multi-vector nature is demonstrated by a combination of formal symmetry with semantic independence of parts (theses), based on the asymmetry of the language sign: homonymy of a phrase or individual words (18), metaphorical reinterpretation (19). There is not just a change of syntactic roles within the semantic limits, but also a transition beyond these limits:

(18) Gib den Regierungen en besseres Deutsch und den Deutschen dafür bessere Regierungen /Adolf Glassbrenner/

Give the governments a better German and the Germans better governments'

/Adolf Glassbrenner/

(19) Dichter ist ein Mensch, der entweder Feuer in seine Verse steckt oder seine Verse ins Feuer /Georg Christoph Lichtenberg/

'A poet is a person who either puts fire into his verses or his verses into fire'

/Georg Christoph Lichtenberg/

In the most common definitions of aphorism, along with the "logical inference", "generalization", "brevity", "expressiveness", "figurativeness", "predicative structure', a combination of the rational and paradoxical features is noted (Karasik, 2002, p. 7; Koval', 2014, URL). The rational-paradoxical relationship is related to the philosophy of general meaning (Deleuze's terminology) and consists in a theoretically mutual exclusion between symbol and meaning. The paradox is based on a logical contradiction and increases along with the number and quality of meanings embedded in the text. In combination with brevity, paradoxicality eliminates complex and gradual argumentation, and thus transforms the persuasive function of classical definitions into the impressive polemical function of aphorisms:

(20) Schriftsteller ist ein Mann, dem das Schreiben schwerfällt /Thomas Mann/.

'A writer is a man who finds it difficult to write' /Thomas Mann/

Having the form of classical definitions, aphorisms violate their laws in order to create paradoxicality. This is also confirmed by self-reflective aphorisms, the figurativeness of which implies a negative attitude of aphorists to formal logic: it is compared to a straitjacket, a "trip up" for a thought:

(21) Logik - die Zwangsjacke der Phantasie /Helmut Nahr/

'Logic is the straitjacket of the imagination' /Helmut Nahr/

(22) Logik - Steigbügel für den Geist /Franz Grillparzer/

'Logic is stirrups for the mind' /Franz Grillparzer/

However, in general, the most typical violation of the definition rules for aphorisms is the explication in the definition of secondary or latent semes of the denotation, which can be considered a prototype component of the category of aphorism:

The impression of randomness of the feature of the denotation, which is the basis of the definition, is genetically determined by taking aphoristic definitions out of the context. So, red cheeks can be considered a random sign of a man:

(23) Mensch ist ein Tier, das rote Backen hat. /Friedrich Nietzsche/

'Man himself is the animal with red cheeks' /Friedrich Nietzsche/

*translated by W. Kaufmann 
But the completeness of intertextual connections with the precedent text Thus Spoke Zarathustra removes randomness - Nietzsche repeatedly emphasized that shame is an integral part of a person:

(24) Scham, Scham - das ist die Geschichte des Menschen /Friedrich Nietzsche/

'Shame, shame, shame - that is the history of man!' /Friedrich Nietzsche/

*translated by Th. Common

Intertextual connections of an aphorism are not exclusively motivational in nature. They make it possible to decode implicit meanings, a process that underlies the ludicrous function of an aphorism. Adequate explication requires some knowledge of:

- precedent texts, personalities:

(25) Wilhelm Tell ist noch immer der einzige Schweizer, den die ganze Welt kennt /Friedrich Dürrenmatt/

'Wilhelm Tell is still the only Swiss person known to the whole world' /Friedrich Dürrenmatt/

(26) Klarheit ist die Höflichkeit des Schriftstellers /Jules Renard/ $\leftarrow$ Pünktlichkeit ist die Höflichkeit der Könige /Ludwig XVIII/

'Clarity is the politeness of writers' $\leftarrow$ 'Punctuality is the politeness of kings' /Louis XVIII/

*The Oxford Dictionary of Proverbs

(27) Psychiater ist ein Arzt, der Leid mit Freud vertreibt

'Psychiatrist is a doctor who drives out suffering with joy (Freud)' [double meaning in German: 'Freud' as 'joy' and 'Freud' as the famous Austrian psychiatrist]

- typical situations, realities:

(28) Abwässer - neuzeitliche Bezeichnung für Rhein, Elbe, Donau und ihre sämtlichen Nebenflüsse /Anonym/

'Wastewater - modern term for the Rhine, Elbe, Danube and all of their tributaries' /Anonym/

- features of mentality, separate axiological identification by the linguistic and cultural community of itself and the environment:

(29) Schweigen ist eine Unterhaltung mit dem Engländer /Heinrich Heine/;

'Silence is a conversation with an Englishman' /Heinrich Heine/

(30) Deutschland ist ein Land, in dem es keine Revolution geben kann, weil man dazu den Rasen betreten müsste /Josif Stalin/

'Germany is a country in which there can be no revolution because you would have to step on the lawn to do so' /Joseph Stalin/

The aphorism reaches the phraseological stage when it turns into a precedent text, and this leads to imitation of its model, as follows:

(31) Historiker ist ein rückwärts gewandter Prophet /Friedrich Schlegel/

'Historian is a backward-looking prophet' /Friedrich Schlegel/

vs

(32) Historiker ist ein rückwärts gewandter Journalist /Karl Kraus/

'Historian is a backward-looking journalist' /Karl Kraus/

The linguistic brightness of the aphorism and, accordingly, its tendency to imprinting are provided by metaphors, among which the following types predominate:

- visual:

(33) A-Die Stehleiter des Alphabets /Hugo Olaerts/

'A -the stepladder of the alphabet' /Hugo Olaerts/

(34) 8: die Eieruhr der Zahlen /Ramon Gomez de la Serna/

'8: the hourglass of the numbers' /Ramon Gomez de la Serna/

- functional:

(35) Video - Fernsehen aus der Konserve /Franz F. Schart/

'Video - canned television' /Franz F. Schart/

(36) Angst ist die Triebfeder des Krieges /George Bernard Shaw/

'Fear is the mainspring of war' /George Bernard Shaw/

* Original

- somatic:

(37) Akrobat ist jemand, der sich den Hals bricht, um sich den Bauch zu füllen /Ambrose Bierce/

'Acrobat is a man who breaks his back to fill his belly' /Ambrose Bierce/

* Original

- synesthesia:

(38) Akzent ist ein akustischer Fingerabdruck /Henry Kissinger/

'Accent is an acoustic fingerprint' /Henry Kissinger/

* Original

(as it is known, the "hallmark" of US Secretary Henry Kissinger - his real name is Heinz Alfred Kissinger, a native of Bavaria - was his strong German accent)

- personification: 
(39) Fremdwörter sind Gastarbeiter der Sprache /Wolfram Weidner/

'Foreign words are guest workers of the language'/Wolfram Weidner/

(40) Beredsamkeit: Gedanken, die atmen, und Worte, die brennen /Thomas Gray/

'Poetry is thoughts that breathe and words that burn' /Thomas Gray/

*Original

\section{CONCLUSION}

This study considers eptonyms as repeated units of a citation nature, associated by speakers with their real or imaginary author. They are presented as multi-sided phenomena - units of language (of phraseological nature) and speech genres. Eptonyms are related to phraseological units in reproducibility and template structure; to speech genres routine and anonymity of reproduction (anyone can quote an eptonym and in any context as a common cliché).

Eptonyms have a number of textual features (microtexts), which is especially reflected in the German tradition of eptonym research, in which it is customary to call such statements "basic texts" because they reflect the general "sociocultural experience".

However, such characteristics do not reflect the specifics of eptonyms in comparison with other microtexts (for example, proverbs, etc.). Therefore, the author's factor as an elite language personality - one that has an advantage over other native speakers in certain types of competencies - was involved in the study of German eptonyms.

Often, the authors of eptonyms that become frequently cited, even in isolation from the author, are a precedentsetting person (which, for German linguoculture, by the way, is Goethe). As a rule, this is due to the importance of these authors for linguoculture, as well as the obligatory nature of their texts.

The aim of our research was to identify the influence of the role of the author and his position on determining the type of eptonym and, accordingly, on the differentiation of related eptonymic genres. In this study, this distinction is made between maxim and aphorism. The establishment of the authorship of quotations and the source of their origin were carried out due to German printed and online publications of dictionaries of quotations and aphorisms, and their discursive use - through the search for these quotations in the online versions of leading German newspapers and magazines. This distinction was made possible by a 4-step algorithm for determining the degree of prominency (highlighting) of the author's personality when quoted in modern discourses. According to this criterion, the maxim and aphorism are prototypes of the minimum (maxim) and maximum (aphorism) author's influence on the content characteristics of the eptonym.

Maxim is a constant expression that objectifies the moral norms of a certain national language collective. Maxim has differential characteristics with regard to other related texts. Maxim is not paradoxical, but rational, it does not actualize humorous content, contains an immanent moral component, has an explicit/implicit directive character, does not demonstrate a diverse or widespread thematic classification, but explicates only the rules of behavior, ethical, moral principles, sometimes objective laws, norms. Maxim rarely contains an assessment; and rhyme is not typical for it.

The main differential feature of the maxim is its normative-moralistic nature and regulativeness, which consists in its explicit (implicit) reference point to a certain ideal, a pattern of behavior established by society in relation to moralistic and normative attitudes.

The aphorism has the following features:1. paradoxicality, reflecting the depth and originality of individual author's thought, a partial manifestation of which is the multi-vector thought, the linguistic embodiment of which is the asymmetry of the sign; 2 . symmetry, which is linguistically manifested in syntactic parallelism, repetitions, chiasms, and other manifestations of balance, including rhythm and sound symbolism; 3. a dialogue with the reader who can also have a chiastic speech manifestation and often contains a denial of generally accepted utilitarian experience; 4 . violation of the principles of formal logic (in particular, defining).

\section{REFERENCES}

[1] Aphorismen.de. Datenbank der 75.000 Aphorismen. http://www.aphorismen.de (accessed 21/7/2021). (in German)

[2] Bakhtin, M.M. (1996). Problema rechevyh zhanrov [The problem of speech genres]. In Bakhtin, M.M. Sobraniya sochinenij. [Collection of works]. Moscow: Russkiye slovari. Vol. 5: Essays of 1940-1960. 159-206 (in Russian)

[3] Berkov, V.P., Berkova, O.V. (2000). O krylatykh slovakh [About winged words]. In Berkov V.P., Mokiyenko V.M., Shulezhkova S.G. (eds) Bol'shoj slovar' krylatykh slov russkogo yazyka [Big dictionary of Russian winged words].. Moscow: Russkiye slovari, Astrel', AST, 3-15 (in Russian)

[4] Blakar, R.M. (1987). Yazyk kak instrument sotsial'noj vlasti. Yazyk i modelirovaniye sotsial'nogo vzaimodejstviyar [Language as instrument of social power. Language and design of social cooperation]. Moscow: Nauka (in Russian)

[5] Das große Z. 10.000 Zitate von 2.300 Autoren zu 5.300 Themen. http://www.zdown.de/ (accessed 11/3/2021)

[6] Das Neue Testament (1992). [New Testament]. Wuppertal und Zürich: Brockhaus Verlag (in German)

[7] Dementyev, V.V. (2010). Teoriya rechevykh zhanrov [Theory of speech genres]. Moscow: Znak (in Russian)

[8] Die Zitate-Welt. Zitate, Aphorismen und Sprüche [Quotations, Aphorisms and Winged Phreases]. http://www.zitate-welt.de (accessed 11/3/2021) (in German)

[9] Dodel, F. (1997). Das Sitzen der Wüstenvater: eine Untersuchung anhand der Apophthegmata Patrum [The Sitting of the Desert Fathers: An Investigation based on Apophthegmata Patrum]. Freiburg, Schweiz: Univ.-Verl. (in German) 
[10] Dyadechko, L.P. (2002). Krylatye slova kak obyekt lingvisticheskogo opisaniya: istoriya i sovremennost' [Winges words as an object of linguistic study: history and modernity]. Kiev: Kiev University Publishing (in Russian)

[11] Fix, U. (2008). Der Spruch - Slogans und andere Spruchtextsorten [The saying - slogans and other sayings]. In Texte und Textsorten: Sprachliche, kommunikative und kulturelle Phänomene. Berlin: Frank \& Timme GmbH, 47-64. (in German)

[12] Gasparov, M.L. (2001). Aforizm. Gnoma. Maksima. Sententsiya. Hriya. Yazykovaya priroda aforizma [Aphorism. Gnome. Maxim. Sentence. Chria. Language nature of aphorism. Essays and extractions]. Mogilev: A.A. Kuleshov Minsk University, (in Russian)

[13] Goethe, J. W. (1997). Lektüre für Augenblicke [Reading for a moment]. Nachwort Gerhart Baumann. Frankfurt am Main: Insel Verlag. (in German)

[14] Harden, Th. (2006). Angewandte Linguistik und Fremdsprachendidaktik [Applied linguistics and foreign language didactics]. Tübingen: Günter Narr Verlag. (in German)

[15] Heinemann, W. (2000). Typologisierung von Texten I: Kriterien Typology of texts I: Criteria. In Klaus Brinker, Gerd Antos, Wolfgang Heinemann und Sven F. Sager (eds.), Text- und Gesprächslinguistik. Ein internationales Handbuch zeitgenössischer Forschung (2. Halbbd.). Berlin/New York: de Gruyter, 507-523. (in German)

[16] Ivanov, E.E. (2001). Iz istorii izucheniya yazykovoj prirody aforizma (XIX-pervaya polovina XX vv.) [From history of study of language nature of aphorism (XIX is the first half of XX century)]. Mogilyov: A.A. Kuleshov Minsk University. (in Russian)

[17] Karasik, V.I. (2002). Yazykovoj krug: lichnost', koncepty, diskurs. [Language circle: personality concepts, discourse]. Volgograd: Peremena. (in Russian)

[18] Koloiz, Zh. V. (2014). Ukrayins'ka paremiologiya [Ukrainian paremiology]. Kryvyi Rih: KNU. (in Ukrainian)

[19] Korol'kova, A.V., Tikhonov, A.N. (2007). Zhenschiny, schastye, lyubov' glazami russkikh pisatelej i poetov: slovar' aforisiticheskikh kontseptov. [Women, happiness, love in the eyes of Russian writers and poets: a dictionary of aphoristic concepts]. Moscow: Flinta. (in Russian)

[20] Koval', O.V. (2014). Semiotizatsiya formy yazykovogo znaka v diskurse [Semiotization of the form of the linguistic sign in discourse] In Feschenko, V.V., Koval', O.V. (eds.), Sotvoreniye znaka: Ocherki o lingvoestetike i semiotike iskusstva [Creation of the sign: Essays on linguoaesthetics and semiotics of art ]. http://kontent.org.ua/stati.html (accessed 19/6/2021) (in Russian)

[21] Krasnykh, V. V. (1998). Virtual'naya real'nost' ili real'naya virtual'nost'?(Chelovek. Soznaniye. Kommunikatsiya) [Virtual reality or real virtuality? (Human. Mind. Communcation)]. Moscow: Dialog Moscow State University (in Russian)

[22] Martynyuk, A.P. (2012). Slovnyk osnovnykh terminiv kohnityvno-dyskursyvnoyi linhvistyky. [A dictionary of the basic terms of cognitive-discoursive linguistics]. Kharkiv: Kharkiv University Publishing (in Ukrainian)

[23] Minayeva, L.V., Pogrebenko, Yu.I. (2001). Frazeologicheskiye osobennosti tsitaty i leksikograficheskaya praktika [Phraseological features of citations and practical lexicography]. Vestnik Moskovskogo gosudarstvennogo universiteta, Seriya 19. Lingvistika i mezhkulturnaya kommunikatsiya [Messenger of Moscow State University, Series 19. Linguistics and intercultural communication], 2, 92-106. (in Russian)

[24] Müller, W. G. (1999). The Iconic Use of Syntax in British and American Fiction. In M. Nänny and O. Fischer (eds). Form Miming Meaning. Amsterdam/ Philadelphia: John Benjamins Publishing Co., 393-408.

[25] Müller, W. G. (2001). Iconicity and rhetoric: A note of the iconic force of rhetorical figures in Shakespeare. In: O. Fischer and M. Nänny (eds) The Motivated sign: iconicity in language and literature 2. Amsterdam: John Benjamins Publishing Co., 305323.

[26] Norrman, R. (1999). Creating the world in our image: A new theory of love of symmetry and iconicist desire. In M. Nänny and O. Fischer (eds). Form Miming Meaning. Amsterdam/ Philadelphia: John Benjamins Publishing Co., 59-82.

[27] Sirotinina, O.B. (1998). Sotsiolingvisticheskij factor v stanovlenii yazykovoj lichnosti [Sociolinguistic factor in the formation of a linguistic personality] Yazykovaya lichnost': sotsiolingvisticheskiye $i$ emotivnyye aspekty [Language personality: sociolinguistic and emotive aspects]. Volgograd - Saratov: Peremena, 3-9 (in Russian)

[28] Slyshkin, G.G. (2000). Ot teksta $k$ simvolu: lingvokulturnyye kontsepty pretsedentnykh tekstov v soznanii $i$ diskurse [From text to symbol: linguocultural concepts of precedent texts linliguistic consciousness and discourse]. Moscow: Academia. (in Russian)

[29] Sovremennyj tolkovyj slovar' [Modern explanatory dictionary] (2003). Moscow: Great Soviet Encyclopedia. https://slovar.cc/rus/bse/502867.html (accessed 19/6/2021) (in Russian)

[30] Svas'yan, K.A. (1989). Johann Wolfgang Goethe. Moscow: Mysl' (in Russian)

[31] Tange, E. G. (1997). Lexikon der boshaften Zitate [Dicationary of evil quotations]. Frankfurt am Main: Eichborn (in German)

[32] Zitate online. http://www.zitate-online.de (accessed 11/3/2021) (in German)

[33] Zitate und Sprüche. http://www.zitate.net (accessed 11/3/2021) (in German)

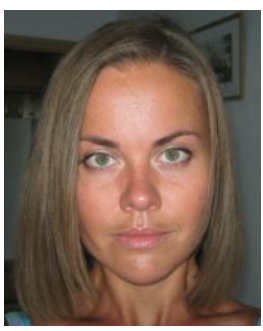

Nataliia Onishchenko was born in Kharkiv, Ukraine, in 1977. She has completed her Specialist degree in German Language and Literature at Kharkiv State University (now called V. N. Karazin Kharkiv National University) in 1999 and has received her $\mathrm{PhD}$ in Germanic Languages (German) from the same University in 2003. Her areas of research include semantics, phraseology, eptology, cognitive linguistics, text linguistics and teacher training.

Currently Dr. Onishchenko is an Associate Professor at German Philology and Translation Department, Deputy Dean for Research, School of Foreign Languages of V. N. Karazin Kharkiv National University, is engaged in international research undertakings in cooperation with the Goethe-Institute of Germany and Ukraine, supervises postgraduate students. She is also member of UDGV (Ukrainian branch of IDV). 


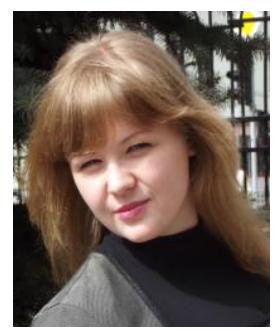

Tetiana Smoliana was born in Kharkiv, Ukraine, in 1983. She has completed her MA in German Language and Literature at V. N. Karazin Kharkiv National University in 2005 and has received her PhD in Germanic Languages (German) from the same University in 2017. Her areas of research include phraseology, eptology, cognitive linguistics, text linguistics, pragmatics and discourse.

Now Dr. Smoliana works as an Associate Professor at German Philology and Translation Department, School of Foreign Languages of V. N. Karazin Kharkiv National University, participates in different trainings and seminars in Ukraine and abroad as well. She is also a member of UDGV (Ukrainian branch of IDV).

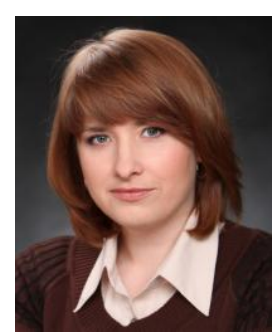

Maryna Miroshnychenko was born on Crimea, Ukraine, in 1976. She has completed her specialist degree in German Language and Literature at Kharkiv State University (now called V. N. Karazin Kharkiv National University) in 1998 and has received her $\mathrm{PhD}$ in Literature of Foreign Countries (German) from the Dnipropetrovsk National University (now called Oles Honchar Dnipro University) in 2006. Her areas of research include German literature of the twentieth century, memory and spatial literary studies.

Dr. Miroshnychenko is now an Associate Professor at German Philology and Translation Department, School of Foreign Languages of V. N. Karazin Kharkiv National University, takes part in international projects, is a member of UDGV (Ukrainian branch of IDV). 